\title{
WestVirginiaUniversity
}

THE RESEARCH REPOSITORY @ WVU

West Virginia Agricultural and Forestry Experiment

Davis College of Agriculture, Natural Resources

Station Bulletins

And Design

$1-1-1903$

\section{Sheep feeding experiments : notes on parasites}

J. H. Stewart

Horace Atwood

Follow this and additional works at: https://researchrepository.wvu.edu/ wv_agricultural_and_forestry_experiment_station_bulletins

\section{Digital Commons Citation}

Stewart, J. H. and Atwood, Horace, "Sheep feeding experiments : notes on parasites" (1903). West Virginia Agricultural and Forestry Experiment Station Bulletins. 90.

https://researchrepository.wvu.edu/wv_agricultural_and_forestry_experiment_station_bulletins/90 @ WVU. It has been accepted for inclusion in West Virginia Agricultural and Forestry Experiment Station Bulletins by an authorized administrator of The Research Repository@WVU. For more information, please contact ian.harmon@mail.wvu.edu. 

Digitized by the Internet Archive in 2010 with funding from Lyrasis Members and Sloan Foundation 


\section{WEST VIRGINIA UNIVERSITY \\ AGRICULTURAL EXPERIMENT STATION}

MORGANTOWN, W. VA.

\section{Sheep Feeding Experiments.}

\section{Notes on Parasites.}

By J. H. STEWART and HORACE ATWOOD.

[The Bulletins and Reports of this Station will bermailed free to any citizen of West Virginia upon written application. Address, Director of Agricultural Experiment Station, Morgantown, W. Va.] 


\section{THE REGENTS OF THE WEST VIRGINIA UNIVERSITY.}

Name of Regent.

P. O. Address. Hox. W. J. W. Cordex...................... Wheeling HoN. С. М. ВАвв .. .... . . . . . . . . . . . . . . Falls HoN. J. B. Finley,.....................Parkersburg Hox. D. C. Galdaher........................ Charleston

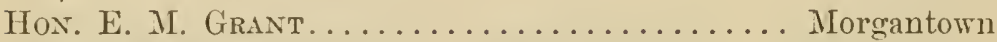
Hox. J. MI. HaLE...................... Princeton MoN. C. E. Haworth ..................... Huntington

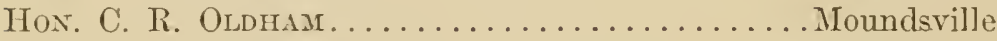
HoN. J. R. ТRоттеR....................... Buckhannon

President of the Board of Regents........... W. J. W Cowden President of the University............... B. B. Purinton Tieasurer....................... R. Whiтенill

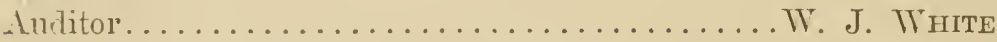

\section{STATION STAFF.}

James II. Stewart, A. M.......... Director and Agriculturist Pert Hite, MI. S............... Vice Director and Chemist JoHN L. SHELDON, РH. D.................... Bacteriologist TT. E. Rudisey, B. S. Agr............ Entomologist in Charge Horace A Twood, M. S. Agr............Assistant Agrieulturist Chias. D. Howard, B. S................Associate Chemist F. B. Kunst..................... Assistant Chemist Gilbert MI. John.................. Assistant IIorticulturist W. J. White......................... Bookkeeper

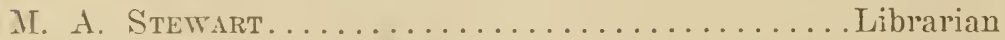

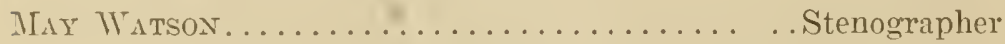




\section{Lamb Feeding Experiments.}

\section{INTRODUCTION.}

One of the important practical problems which confronts the sheep-raiser in West Virginia is how to obtain the most profit from the lambs which must be disposed of each year. The common practice of selling the surplus as soon as the grass becomes short in the fall has some advantages and some serious disadvantages. Among the greatest of these disadvantages stands the fact, that the market price of fat lambs in the fall is generally lower than at any other time of the year. This statement is sustained by an examination of weekly quotations averaged according to months for a series of years. During the fourteen years ending January 1st., 1903, the average selling price, per hundred pounds, of choice lambs in the Pittsburg market, which is fairly typical of all the large markets, has been as follows:

January, \$5.82; February, \$5.94; March, \$6.11; April, \$6.11; May, \$5.74; June, \$5.22; July, \$5.70; August, \$5.41; September, $\$ 5.37$; October, $\$ 5.21$; November, $\$ 5.13$; December, $\$ 5.38$.

These prices represent the average of the highest weekly quotations, in a wholesale way, of choice lambs as quoted in the "National Stockman and Farmer" a paper whose editor has given careful attention to market reports for a number of years. The season for the marketing of lambs begins with July and continues until the next July, and in these averages no notice has been taken of the price of "spring lambs" for which there is a limited demand at special prices.

As the period covered is the past fourteen years we may assume that the figures represent with a fair degree of accuracy the general tenor of the lamb market. Let us therefore examine these average prices carefully. 
hay worth ten dollars per ton, and the corn one cent per pound, then the cost of one pound gain for the lambs receiving cowpeas was 6.79 cents and for the lambs receiving the mixed hay 51.77 cents.

The lambs were bought for four and one-half cents per pound, and the entire flock including lot 3, was sold for five cents. The following table shows the financial results of the experiment with lots one and two.

\begin{tabular}{|c|c|c|c|c|}
\hline Original Cost. & $\begin{array}{c}\text { Cost } \\
\text { of Food. }\end{array}$ & $\begin{array}{l}\text { Total } \\
\text { Cost. }\end{array}$ & $\begin{array}{l}\text { Selling } \\
\text { Price. }\end{array}$ & $\begin{array}{l}\text { Gain or } \\
\text { Loss. }\end{array}$ \\
\hline $\begin{array}{l}05.30 \\
\text { U5.84 }\end{array}$ & $\begin{array}{l}\$ 18.34 \\
\$ 24.85\end{array}$ & $\begin{array}{l}\$ 123.64 \\
\$ 131.69\end{array}$ & $\begin{array}{l}\$ 130.50 \\
\$ 120.00\end{array}$ & $\begin{array}{l}\text { 6.86 Gain } \\
10.69 \text { Loss }\end{array}$ \\
\hline
\end{tabular}

The table shows that the lambs fed cowpeas gave a slight profit, while the others were fed at a loss. In neither case did the increase in live weight pay for the food consumed for its production. It is to be observed, too, that the entire flock was sold at a uniform price. In fact, however, lot 1 was easily worth five and one-half cents per pound, and at that price the profit would have been $\$ 19.91$, or a little more than fifty cents per head.

Although a small profit was obtained from the lambs fed on cowpea hay, yet the experiment clearly shows that it is not wise to attempt to fatten lambs unless they are in a healthy, vigorous condition, at the beginning of the feeding period.

\section{RESULT FOR 1901.}

In the fall of 1901 fifty-two lambs were purehased, which were supposed to be free from stomach worms. A short time after the beginning of the feeding test however, about one-third of them showed the characteristic symptoms of the presence of stomach worms. These receired the benzine treatment, and the experiment was continued.

The test was begun January 2nd, 1902, and was continued for nine weeks. The lambs were divided into two uniform lots, twenty-six lambs in each. Lot 1 was fed corpea hay and shelled corm, while lot 2 received mixed timothy and clover hay and shelled corn.

The following table gives the original weight of each lot of 
lambs, the gain in live weight during the nine weeks of the test, and the amount of grain and forage weighed out for them. They were supplied all the forage that they would eat up fairly clean.

\section{Lot 1. 1910 .}

Lot 2. 1912...

\section{Gain in Cowpea Mixed Shelled Live Weight. Hay. Hay. Corn. $378 \quad 5380$ \\ 223 \\ 2950 648 648}

If the corn and forage be valued the same as in the preceding test, then the cost of one pound gain for the lambs receiving corpeas was five and trenty-seven hundredths cents and for those receiving mixed hay nine and fifty-two hundredths cents.

The lambs were purchased in the fall for four and one-half cents, and were sold in the local market for five cents per pound. The following table shows the financial results of the experiment:

$\begin{array}{llrrrrr} & & \text { Cost. } & \text { of Feed. } & \text { Cost. } & \text { Price. } & \text { Gain. } \\ \text { Lot 1. Cowpeas ............. } \$ 81.17 & \$ 19.93 & \$ 101.10 & \$ 114.40 & \$ 13.30 \\ \text { Lot 2. Mixe.1 Hay ....... } & \$ 81.26 & \$ 21.23 & \$ 102.49 & \$ 106.75 & \$ 4.26\end{array}$

In spite of the fact that about one-third of the lambs in this test were affected with stomach worms and did not fatten as well as though they had been free from these parasites, yet those which received the cowpea hay gave a net profit of slightly more than fifty cents per head. The other lot, however, did not make such a satisfactory showing.

\section{RESULT FOR 1902.}

This feeding test was begun December 11th, 1902, and wạs continued for serenty-three days. The lambs used were natives and grade Southdowns, purchased from farmers near Morgantown. The attempt to obtain lambs which were not infested with stomach worms was partially successful although a few of them began to scour badly soon after the beginning of the feeding test. Each of these received a drench of three ounces of a one per cent solution of coal-tar creosote. This remedy seemed to be considerably more efficient than the gasoline treatment employed in former years.

The lambs were divided into two uniform lots of thirty-seven 
each. Lot 1, received cowpea hay and corn, and lot 2 mixed timothy and clover hay and corn.

The following table shows the weight of the lambs at the beginning and at the end of the test, and the amount of corn and forage consumed.

\begin{tabular}{|c|c|c|c|c|c|c|}
\hline \multirow[b]{3}{*}{ Lot 1- } & \multirow{3}{*}{$\begin{array}{l}\text { We }: \text { ht } \\
\text { Dec } 11 .\end{array}$} & \multirow[b]{2}{*}{ Weight } & \multirow{2}{*}{$\begin{array}{c}\text { Gain in } \\
\text { Live }\end{array}$} & \multicolumn{2}{|c|}{ Consumed } & \multirow{3}{*}{ Corn. } \\
\hline & & & & Cowpea & Mixed & \\
\hline & & Feb 23 & Weight. & Hay. & Hay. & \\
\hline $\begin{array}{l}7 \text { Lambs } \\
\text { Lot } 2-\end{array}$ & 2275 & 2770 & 495 & 4020 & ... & 1629 \\
\hline Lambs & 2280 & 2480 & 200 & .. & 3480 & 1629 \\
\hline
\end{tabular}

Valuing the forage and grain the same as in previous tests, then the cost of one pound of increase in live weight was 3.32 cents for lot 1 , and 16.84 cents for lot 2 .

The lambs cost five cents per pound and were sold in the local market for five and one-half cents. The following table shows the financial results of the experiment.

Lot 1 ..

$$
\begin{aligned}
& \text { ros. Cost of Total Selling Profit or Loss. }
\end{aligned}
$$

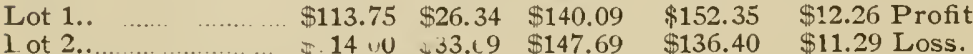

As in previous years the lambs which received cowpea hay made a larger increase in live weight and at a lower cost than those which were fed mixed clover and timothy.

\section{CONCLUSION.}

Valuing the cowpea hay at five dollars per ton, the mixed hay at ten dollars and the corn at one eent per pound, then the lambs which reccived cowpea hay were fed each year at a profit, while those receiving mixed hay were profitable in only one instance.

Practically none of the lambs gained in weight as rapidly as they should. This was due partially to the presence of internal parasites which interfered with the process of digestion and assimilation and partially to the inbred and debilitated flocks prevailing in this section from which the lambs were derived. 


\title{
Notes on Parasites.
}

\author{
STOMACH WORMS. \\ (Strongylus Contortus.)
}

Stomach worms, or the Twisted Strongyles, seriously interfere with successful sheep husbandry in this and other sections of the country. They are small, slender worms from threefourths to one inch long, and are found principally in the fourth stomach of sheep, either adhering by their mouths to the mucus membrane or collected in clumps or balls. Large inumbers, or only a few, may be present. Sometimes their color is white and sometimes reddish, due to the blood which has been sucked from the victim. The females are considerably larger than the males. The following" plate from "Animal Parasites of Sheep" published by the Bureau of Animal Industry, shows the details of their structure. 


\section{STRONGYLUS CONTORTUS. Rud.}

Fig. 1.-Adult female, $x 6$; $a$, head; $b$, ovaries wound around the intestines; c, c, uteri; $d$, a large papillæ, just in front of and covering the vulva; e, anus.

Fig. 2.-Adult male, $\mathrm{x} 6$.

Fig. 3.-Head; a, two barb-like papillæ; b, mouth; c, oesophagus; d, intestine.

Fig. 4.-Egg, highly magnified: a, eggs before they have left the oraries; b, eggs showing nuclei; $c$, eggs after they have passed through the ovidnct; d, egg with one cell; e, with two; f, with four; g, with eight; h. with many; i, egg as it is laid.

Fig. 5.-Skin, showing nine of the 18 longitudinal lines.

Fig. 6.-Female: a, intestine; b, b, the ends of the ovaries.

Fig. 7.-Caudal end of Female; a, the anus; b, the vulva; $c$, vagina; $d, d$, uteri filled with eggs; $e$, oviduct; $f$, f, ovary; $g$, intestine.

Fig. 8.--Spicula, enlarged.

Fig. 9.-Bursa, expanded to show costæ; a. ventral; b, ventrolateral; c, lateral; d. dorso-lateral; e, dorsal ; f, spicula.

Fig. 10.-Group of adult males and females natural size.

Fig. 11. - Caudal end of male; a, bursa; b, spicula; c, seminal reservoir; $d$, intestine.

\section{LIFE HISTORT.}

The life history of these worms is apparently simple. The eggs from the mature females fall to the ground, where they live for a time in moist earth or stagnant water, undergo certain changes in structure and are then swallowed by sheep or lambs while grazing or drinking. After reaching the fourth stomach they complete thcir development, and more eggs are then scattered over the pasture.

\section{STMIPTOMS.}

There are no special particular symptoms which indicate the presence of stomach worms, as the same symptoms of disease may be produced by the presence of other intestinal parasites. Lambs are usually more seriously affected than old sheep which have a greater power of resistance. The first trouble which is noticed is that the lambs are not growing as rapidly as they 


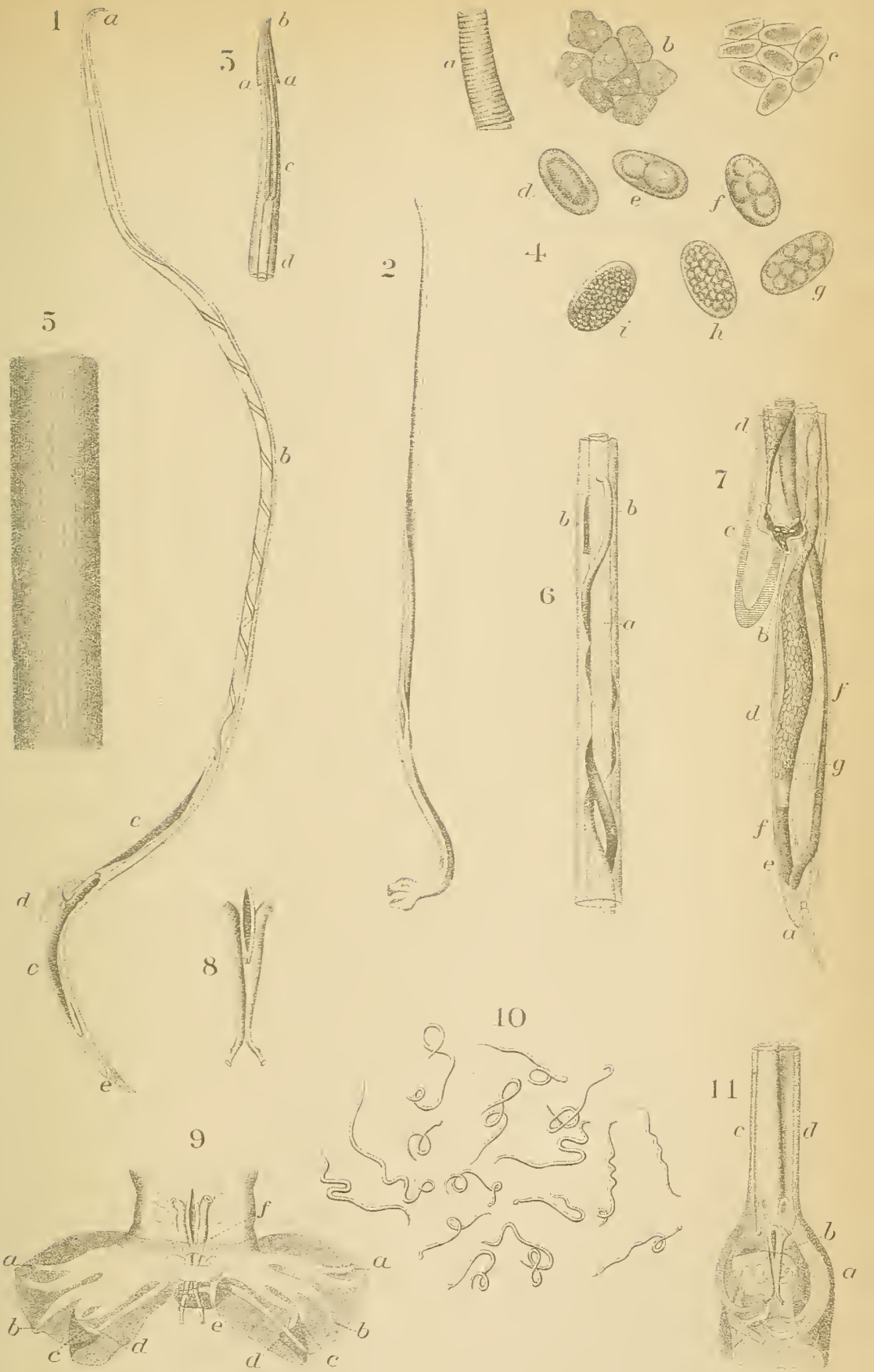

Geo. Marx, del. 

should. Soon those which are affected worse, become gaunt, lag behind the rest of the flock, and have an unhealthy dejected appearance. The ears droop, the droppings become soft, and death finally results from weakness or lack of nutrition.

TREATMENT.

Of the many remedies proposed there are only two worthy of the name. These are benzine or gasoline, and coal-tar creosote. The first remedy has been used longer than the other, is better known, and has been employed with excellent results in many well authenticated cases.

\section{THE JULIEN BENZINE TREATMENT.}

Before giving the medicine food and water should be withheld from the lamb during the night and until about ten o'clock the next day. Then the gasoline or benzine is given and the lamb is allowed to remain two or three hours longer before being supplied with food and water. This process of withholding food and water and administering gasoline is repeated for two more days.

The usual doses of gasoline for stomach worms are as follows: (Bureau of Animal Industry, Report, 1901.)

Lambs..
Sheep
Calves
Yearling Steers

This is equivalent to an orsinary tablespoonful for lambs weighing from 60 to 80 pounds. Each dose is mixed separately in four ounces of flax-seed tea or sweet milk. The bottle containing the mixture should be shaken thoroughly so as to emulsify the gasoline and the drench given at once. Care should be taken not to strangle the animal. According to the Ohio Experiment Station, the sheep should be set up on its haunches, while the dose is being given, but the Bureau of Animal Industry gives the advice to administer the drench while the animal is standing, claiming that more of the medicine will enter the fourth stomach when administered in this way than when the sheep is set on its haunches. The first method is more convenient while probably the second way is more efficient. Occasionally one of the animals is overcome by the gasoline, froths at the mouth and appears to be dying. In such cases a teaspoonful of aromatic 
spirits of ammonia given in water as a drench will speedily revive the animal.

The objections which have been urged against this treatment have been summed up as follows: (Bureau of Animal Industry, Report, 1901.)

"(1).-Not less than three doses, and usually four to six, are required to expell the worms. Its use involves a great expenditure of labor, and it is therefore, impracticable on the large ranches."

"(2).- While several doses are not necessarily injurious to the stock, still, if the doses are large, repeated drenches canse a more or less severe congestion of the bowels. Not only that, but repeated handling of range sheep, with the necessary preliminary treatment of withholding food, is injurious to the animal."

"(3).-If used on animals suffering from pleurisy it is likely to be fatal. I have had several fatal cases of this kind."

"Nearly all vermifuges are, however, more or less poisonous in one way or another, and gasoline, if properly used, is not particularly dangerous. The necessity of repcating the dose from four to nine times in order to effect a complete cure will, however, militate against its general adoption."

\section{COAL-TAR CREOSOTE.}

The following quotations concerning the use of this remedy are taken from the report of the Burean of Animal Industry for 1901.

"I have had excellent success in treating sheep, goats, and cattle for the twisted wireworm (Strongylus Contortus), with a one per cent. solution of coal-tar ereosote. The medicine is easily prepared and quite inexpensive. It may be purchased of a druggist in small quantities of one ounce, or in pound bottles. One ounce is sufficient for about twenty adult sheep, and the cost of treatment is less than one-half a cent per head; if creosote is purchased by the pound, the cost is reduced to less than one-quarter of a cent per head. If creosote is called for at a drug store, beechwood creosote will usually be dispensed. This is more expensive than the coal-tar creosote and not so satisfactory in expelling worms." 
"A one percent. solution of coal-tar creosote is made as follows:

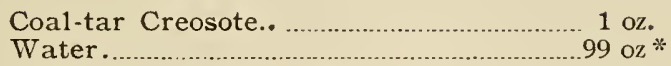

"Twisted wire worms (Strongylus Contortus), taken directly from the stomach of sheep or cattle die in one-half to one and one-half minutes, when immersed in this solution."

"If, in dosing, this liquid enters the lungs, the animal may succumb in a few minutes. If the dosing is performed carefully, as much as six and two-thirds ounces may be given full grown sheep without fatal results. In some cases, however, the animals show ill effects from which it usually recovers within half an hour. Six ounces were given to a number of sheep without the slightest ill effects. The following table gives the doses of the one per cent. mixture which were used in about 400 cases without ill effect:"'

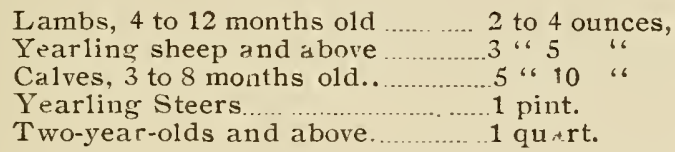

"Sheep, goats, and calves which received this treatment showed a marked improvement a few days after receiving a single dose."

"In experiments with creosote at Washington, D. C., sheep were drenched with the one percent solution and killed immediately afterward. Upon opening the fourth stomach, it was found that the wire worms present were dead."

"If an overdose is given by mistake, and if the sheep appear severely affected by it, the animal should be placed in the shade. Even in some cases of very severe over-doses, when the animal is given up for dead practically, it may entirely recover within an hour or so."

\section{"COAL-TAR CREOSOTE AND THYMOL.}

If, in addition to the stomach worms, the animal should be suffering from a severe infection of bowel worms, such as the hookworm, better results were obtained in the treatment when pow-

*99 ounces equals 6 pints and 3 ounces. 



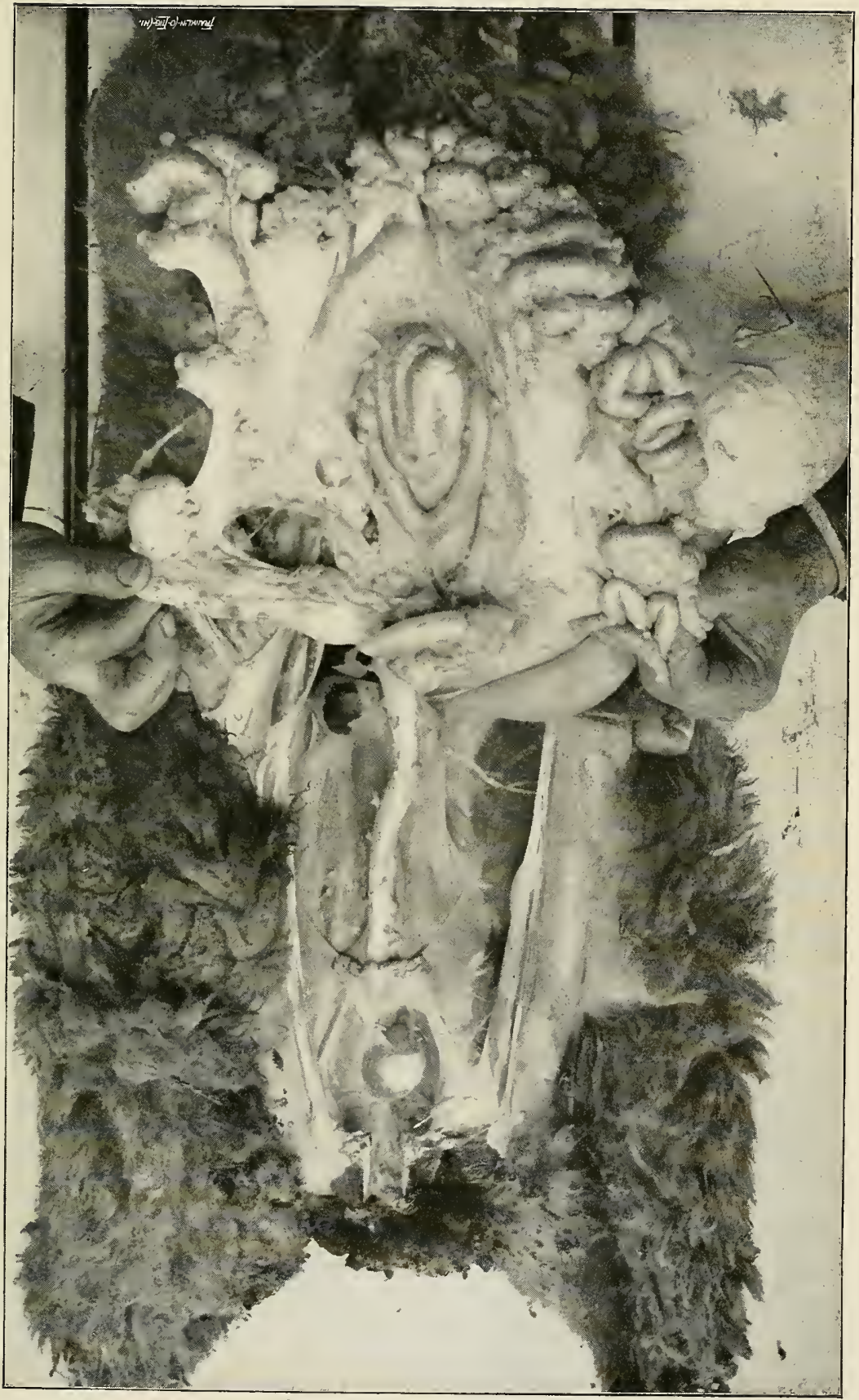

b Viscera of Diseased Sheep Showing Nodules. 

creosote. A. HEALTHIER LOT OF EWES AND LAMBS I NEVER HAD, INCLUDING THE LITTLE ONE DROPPED IN JULY. IT WAS A PERFECT SUCCESS. They were all summer on old pastures that ought to have infected them if there is anything in the theory of the worms or eggs living over in the ground.

We have had a very severe drought since April and that probably helped to keep all healthy. If I live till next spring I shall repeat the experiment, and should the season be wet and my lambs be healthy it will settle the question in my mind and I will double my flock of sheep and correspondingly reduce the number of cattle. Allow me to thank you for suggesting the creosote. I hesitated about using gasoline on account of danger of administering it, as well as trouble to give it so often.

Very truly yours,

Peter S. Couch.

If future experiments show, as they probably will, that stomach worms can be expelled so thoroughly from the mature members of a flock as to prevent the infection of the lambs, then this pest will at once lose its serious character.

Other preventive remedies which have been proposed by various writers and which are more or less efficient are as follows:-

Wean the lambs early and place tliem in a pasture where old sicep have not been allowed to graze. Place all sick animals by themselves.

Supply plenty of salt.

The water supply should not be contaminated by the droppings, or by the wash from the pastures.

Whenever practicable, burn over the pastures. The heat from the burning grass will destroy many of the eggs and embryos.

\section{THE NODULAR DISEASE OF THE INTESTINES.}

(Oesophagostoma Columbianum.)

This malady appears to be widely diffused in this country. According to Dr. D. E. Salmon, it is the chief obstacle to successful sheep husbandry in the southern states. Nor is it confined to the south, for even as far north as New York it sometimes causes serious trouble.

In the fall of 189860 lambs were purchased by the Station from a farmer in the vicinity of Morgantorn for use in a lamb fattening experiment. Most of these lambs were infested with 
this parasite. The plates $a$ and $b$ show the characteristic appearance of the intestines of the diseased lambs. The nodules or "lnots" as they are frequently called, range in size from very small to 1-2 inch in diameter, and are filled with cheesy matter containing the worm which causes the trouble. The symptoms of the disease are not particularly different from those caused by other intestinal parasites. Usually the older sheep of the flock are seriously affected rather than the lambs and yearlings. A sure diagnosis ean be made only by a post mortem examination.

The mature worms, which are 1-2 inch long and which may be found in the large intestine, appear to do very little harm. The immature worms, however, which penetrate the walls of the intestines, causing inflammation which results in the formation of tumors, are the main source of injury. When the tumors are present in large numbers the digestive system is disturbed and the sheep is insufficiently nourished.

According to Curtice, (Animal Parasites of Sheep), these parasites may reach sexual maturity in either of two ways. (1).-By the embryo entering into the intestinal wall where its development is retarded in the nodule which is formed, and from which it subsequently escapes, or (2).-the embryo may develop mormally in the intestine without at any time entering the intestinal wall.

\section{TREATMENT AND PREVENTION.}

Medicinal treatment seems to be of little value, as any remedy strong enough to kill the embryos encrsted in the intestinal walls would kill the sheep. With wise management, however, this trouble can usually be prevented from becoming serious. The flock should be severely culled, and those showing signs of weakness or debility should be disposed of. New blood should be introduced regularly so as to keep up the vigor of the flock, and only the strongest and most rigorous ewe lambs should be retained on the farm. Low wet lands should either be drained or pastured by cattle, and the higher and dryer places reserved for the sheep. 

